\title{
RANCANG BANGUN SISTEM INFORMASI PENEMPATAN AREA KERJA CLEANING SERVICE UNTUK MENINGKATKAN PELAYANAN BANDARA
}

\author{
Euis Sitinur Aisyah*1, Bayu Pramono², Haris Munandar ${ }^{3}$ \\ ${ }^{1,2}$ Program Studi Sistem Informasi Universitas Raharja, ${ }^{3}$ Program Studi Sistem Informasi \\ Universitas Raharja \\ email : ${ }^{1 *}$ euis@ raharja.info, ${ }^{2}$ bayupramono@ raharja.info, ${ }^{3}$ haris.munandar@ raharja.info
}

\begin{abstract}
Abstraksi
Bandara merupakan salah satu gerbang masuk suatu negara, didalam bandara banyak terdapat divisi kerja yang mendukung dan memperlancar seluruh kegiatan yang ada, salah satunya yaitu cleaning service yang memiliki fungsi yang cukup besar yaitu guna meningkatkan kebersihan dan kenyaman didalam area bandara, cleaning service yang ada saat ini di kelola perusahaan dan bekerja sama dengan perusahaan yang berfokus pada jasa cleaning service di setiap terminal. Penempatan area cleaning service masih manual dan banyak memakan waktu dan melibatkan beberapa bagian pada prosesnya, dan menghambat dalam segi waktu pada proses pembersihan area yang ada di bandara sehingga dapat mengurangi mutu pelayanan yang berdampak pada ketidaknyamanan, untuk mengatasi masalah tersebut peneliti berusaha menganalisa lebih lanjut sistem yang saat ini berjalan untuk mengetahui komponen permasalahan yang ada. Hasil yang ingin dicapai pada penelitian ini adalah penerapan sistem yang memudahkan dalam prosesnya yaitu dengan membuat sistem informasi penempatan area kerja cleaning service berbasis web yang dijadikan acuan dalam proses pengembangan sistem nantinya. Metode analisa yang digunakan dalam penelitian ini menggunakan metode PIECES, untuk membantu dalam proses analisa sistem yang telah berjalan. Adapun Bahasa Pemrograman yang digunakan dalam membangun sistem ini menggunakan PHP, MySQL sebagai database untuk menyimpan data-data master, transaksi dan usernya.
\end{abstract}

Kata kunci: Cleaning service, Penempatan area kerja, Meningkatkan pelayanan

\begin{abstract}
The airport is one of the entry gates of a country, in the airport there are many work divisions that support and facilitate all existing activities, one of which is a cleaning service that has a large enough function that is to improve cleanliness and comfort in the airport area, cleaning services that exist when This is managed by the company and works with companies that focus on cleaning service in each terminal. The placement of the cleaning service area is still manual and takes a lot of time and involves several parts in the process, and inhibits in terms of time in the process of cleaning the area at the airport so that it can reduce the quality of services that have an inconvenience, to overcome the problem. which is currently running to find out the components of the problem that exist. The results to be achieved in this study is the application of a system that facilitates the process, namely by making an information system placement of web-based cleaning service work areas that is used as a reference in the system development process later. The analytical method used in this study uses the PIECES method, to assist in the process of analyzing the system that has been running. The Programming Language used in building this system uses PHP, MYSQL as a database to store master data, transactions and users.
\end{abstract}

Keywords: Cleaning service, Placement of work area, Improving service 


\section{PENDAHULUAN}

Sistem informasi berbasis komputer di era globalisasi mengalami perkembangan yang sangat pesat hampir di semua bidang [1]. Hal ini dikarenakan peran teknologi komputer yang memberikan banyak kemudahan dan keuntungan pada semua bidang dan salah satunya dalam dunia kerja, memiliki keunggulan dalam bidang teknologi khususnya komputer dapat menjadi nilai tambah bagi perusahaan yang ingin meningkatkan kinerja dan efektivitasnya waktu kerja [3].

Kemajuan Teknologi yang semakin berkembang pesat memicu pertumbuhan sistem informasi dalam segala bidang [7]. Hal ini terbukti dengan banyaknya peursahaan yang sudah memanfaatkan sistem informasi dalam kegiatan perusahaannya. Setiap manusia yang bekerja pasti akan mendapat berbagai macam tugas untuk memajukan dan demi kelangsungan perusahaan tersebut. Oleh karena itu untuk dapat mengerjakan tugas tersebut, maka dibutuhkan sistem informasi yang tepat untuk mencapai tujuan perusahaan. Pada departemen cleaning service banyak sistem yang belum terkomputerisasi salah satunya penempatan area kerja yang saat ini masih menggunakan sistem yang manual.

Suatu sistem yang terotomatisasi dapat membantu petugas dalam menyelesaikan kewajibanya dangan lebih cepat sehingga mengurangi tingkat keterlambatan yang akan mengganggu stabilitas perusahaan. [5] Penempatan adalah proses penugasan/pengisian jabatan atau pengisian jabatan atau penugasan kembali pegawai pada tugas/jabatan baru atau jabatan yang berbeda. Penugasan ini dapat berupa penugasan pertama untuk pegawai yang baru direkrut, tetapi dapat juga melalui promosi, pengalihan, dan penurunan jabatan bahkan pemutusan hubungan kerja.

Penempatan tenaga kerja adalah proses pemberian tugas dan pekerjaan kepada tenaga kerja yang telah lulus seleksi untuk melaksanakan sesuai ruang lingkup yang telah ditetapkan serta mampu 11 mempertanggung jawabkan segala resiko dan kemungkinan-kemungkinan yang terjadi atas tugas dan pekerjaan, wewenang, serta tanggung jawabnya. [2]

Perancangan Sistem adalah suatu kegiatan membuat desain teknis berdasarkan kegiatan pada waktu proses analisis. Perancangan disini dimaksudkan suatu proses pemahaman dan peran suatu sistem informasi berbasis komputer. [4] Metode PIECES digunakan untuk mengidentifikasi kelemahan sistem yang menjadi rekomendasi untuk perbaikan-perbaikan yang harus dibuat pada sistem yang akan dikembangkan. [13]

\section{METODE PENELITIAN}

Metode penelitian merupakan suatu tata cara atau kegiatan pelaksanaan penelitian rangka untuk mengumpulkan informasi atau data serta melakukan investigasi terhadap data yang telah didapatkan tersebut, yang didasari oleh asumsi-asumsi dasar, pandangan-pandangan filosofis dan ideologis, pertanyaan dan isu-isu yang dihadapi [6][10]. Suatu penelitian mempunyai rancangan penelitian tertentu [8]. Rancangan ini menggambarkan prosedur atau langkahlangkah yang harus ditempuh, waktu penelitian, sumber data dan kondisi arti untuk apa data dikumpulkan dan dengan cara bagaimana data tersebut dihimpun dan diolah untuk dianalisa dalam pembuatan laporan [9].

\section{Metode Observasi (Observasi Research)}

Pada tahapan ini penulis melakukan pengamatan langsung dari objek penelitian untuk mendapatkan data dan informasi yang akurat dan lengkap dari berbagai pihak yang terkait dan berhubungan dengan tema penelitian yang berhasil penulis rumuskan.

\section{a. $\quad$ Metode Wawancara (Interview Research)}

Penulis melakukan wawancara dengan bagian cleaning service yang mengolah data penempatan area kerja, penulis mendapatkan informasi berkaitan dengan penelitian penulis.

\section{b. $\quad$ Metode Studi Pustaka (Studi Literature)}


Selain melakukan observasi penulis juga melakukan data dengan cara studi pustaka dalam metode ini penulis berusaha untuk melengkapi data-data yang diperoleh dengan membaca dan mempelajari dari buku-buku dan data-data yang relevan [11]. Buku dan data tersebut digunakan penulis untuk membantu penganalisaan dan perancangan yang dilakukan.

\section{Metode Analisis Data}

Pada penelitian ini, metode analisa dilakukan dengan langkah-langkah melakukan pengamatan dan analisa terhadap sistem yang berjalan saat ini, serta menentukan UML (Unified Modeling Language) yang meliputi use case diagram, activity diagram, sequence diagram.

\section{HASIL DAN PEMBAHASAN}

Untuk dapat menggambarkan prosedur secara keseluruhan diperlukan bebrapa tahapan analisa sebagai bentuk pengumpulan informasi guna mendapatkan model yang sesuai dengan kebutuhan dan mampu memberikan solusi dengan cepat secara efektif dan efisien [12], mulai dari tahapan pengumpulan informasi dan kebutuhan, analisa dokumen, merancangan hubungan antar dokumen sampai dengan merancanga model diagram database dan model rancangan sistem. Beberapa tahapan yang dimaksud sampai dengan model ranangan yang diciptakan dapat dilihat pada gambar 1,2,3,4,5.

\section{Use Case Diagram Prosedur Berjalan}

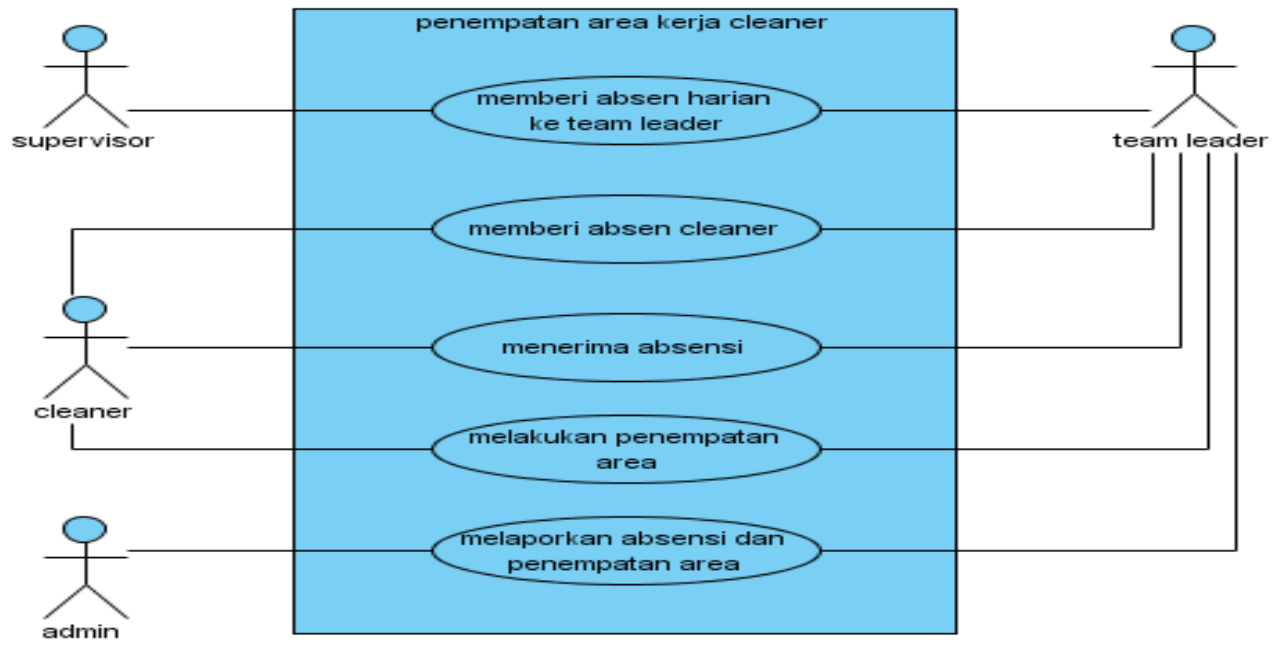

Gambar 1. Use Case Diagram

Berdasarkan gambar use case Diagram (gambar 1) yang berjalan saat ini sistem yang mencakup seluruh kegiatan pada sistem penepmpatan area kerja. Terdapat 4 (empat) Actor yang melakukan kegiatan yaitu supervisor, team leader, admin, team leader yang berfungsi menangani pembuatan absensi, mengisi absensi, pembuatan laporan penempatan area, dan melaporkan penempatan area kerja. 
Terdapat juga 5 (lima) use case yang merupakan proses yang terjadi pada sistem berjalan yaitu membuat absen harian yang dilakukan oleh supervisor, dan team leader menerima absensi dan diberikan langsung kepada cleaner, setelah diisi oleh claner absensi diberikan lagi ke team leader, dan penempatan area kerja dilakukan berdasarkan data absensi. Setelah itu team leader melaporkan kepada laporan penempatan area kerja kepada admin.

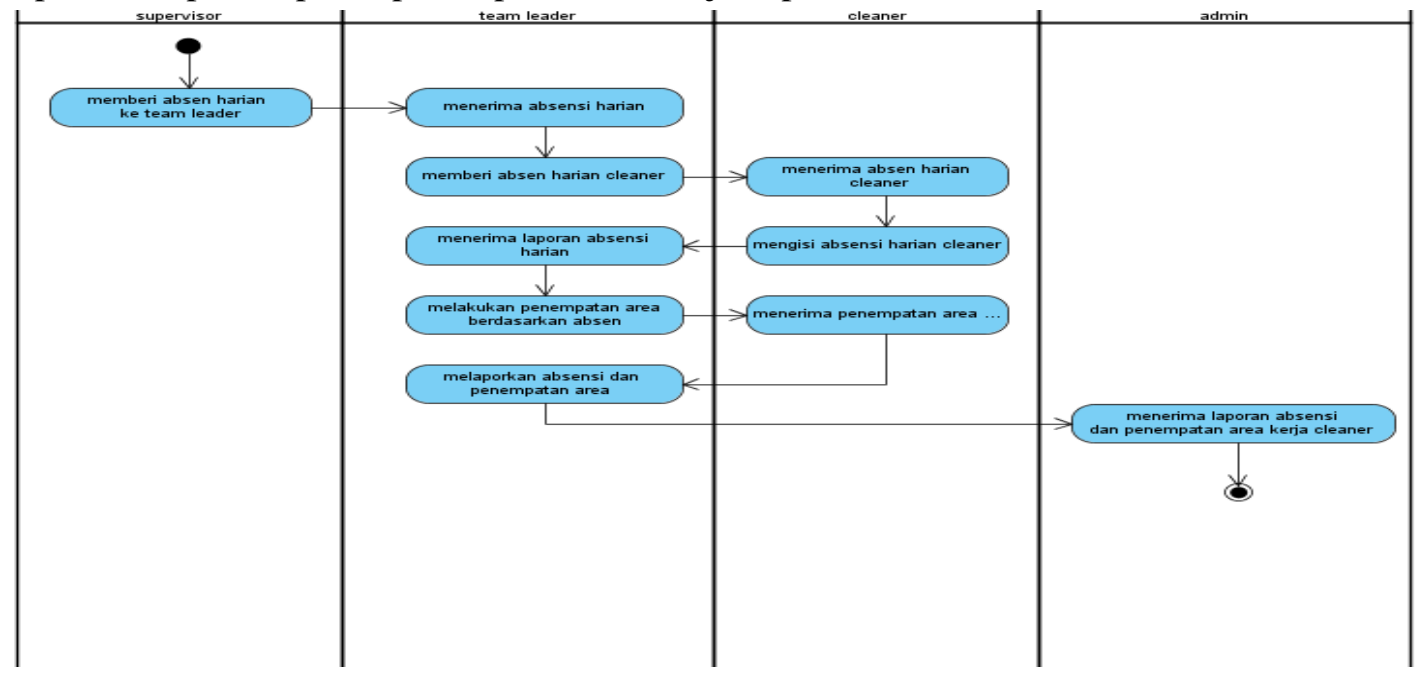

Gambar 2. Activity Diagram

\section{Activity Diagram Prosedur Berjalan}

Berdasarkan gambar activity diagram (gambar 2) yang berjalan saat ini sistem mencakup seluruh kegiatan pelaporan hutang dagang. Sistem ini melibatkan 4 (empat) Actor yaitu, supervisor team leader cleaner admin yang menangani pembuatan absensi, kemudian melakukan absensi, penempatan dilakukan oleh team leader berdasarkan data absensi yang masuk yang sudah diisi oleh cleaner, dan admin menerima laporan penempatan area dan absensi.

\section{Squence Diagram Prosedur Berjalan}

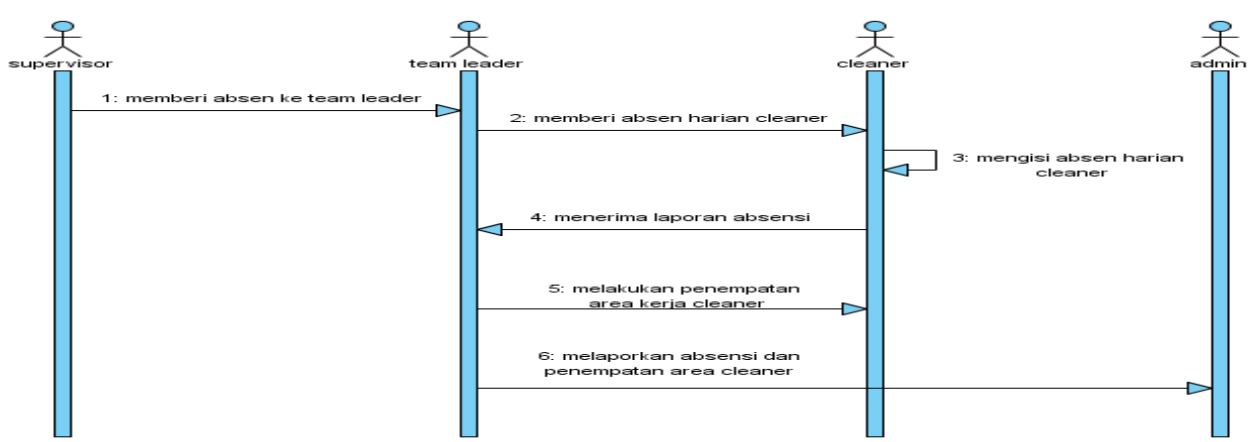

Gambar 3. Squence Diagram

Berdasarkan gambar sequence diagram (gambar 3) yang berjalan saat ini terlihat 4 (empat) actor yang melakukan kegiatan diantaranya: supervisor team leader cleaner admin, manager keuangan dan direktur utama, yang akan menyelesaikan 6 message spesifikasi dari komunikasi antar objek yang memuat informasi-informasi tentang aktifitas yang terjadi, yaitu pemberian absensi ke team leader, memberikan absensi ke cleaner, absensi diisi oleh cleaner, menerima laporan absensi, melakukan penempatan area kerja, melaporkan absensi dan penempatan area kerja.

Rancangan diatas (gambar 1, 2, 3) merupakan gambaran prosedur yang berjalan dimana pada tahapan ini melibatkan beberapa dokumen seperti absensi harian dan laporan penempatan 
area kerja. Dimana absensi dibuat oleh supervisor untuk mendata karyawan yang masuk kerja dan laporan penempatan area kerja dibuat oleh team leader untuk menugaskan cleaner untuk menempati area yang sudah di berikan dan laporan tersebut di berikan kepada admin.

\section{Class Diagram}

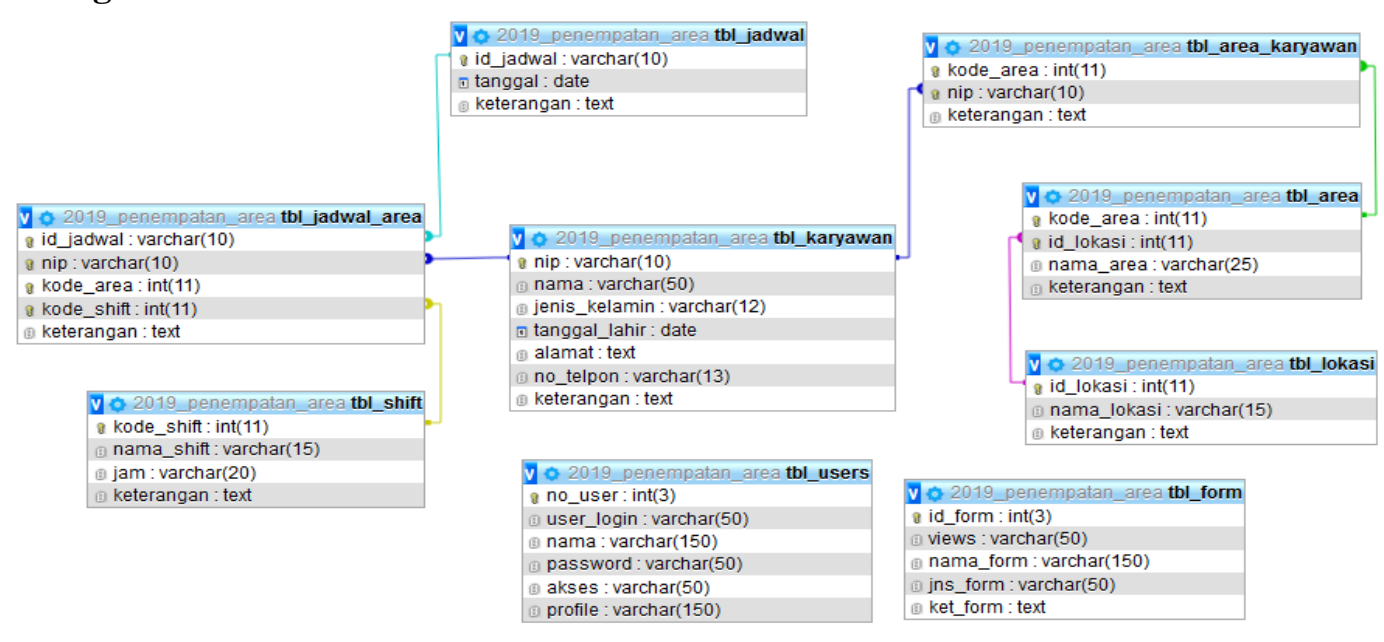

Gambar 4. Class Diagram

Berdasarkan gambar class diagram (gambar 4) yang berjalan saat ini sistem yang mencakup seluruh kegiatan pada sistem penempatan area kerja. Terdapat 9 (sembilan) class yaitu user, form, jadwal yang merupakan tabel transaksi dan area, area_karyawan, karyawan, shift, jadwal_area sebagai tabel master.

Berdasarkan gambar class diagram (gambar 4) diatas dapat dilihat dengan jelas bahwa tingkat hubungan karyawan dan area_karyawan yaitu one to many (1:M), tingkat hubungan area dan lokasi one to many (M:1), tabel jadwal_area tercipta karena adanya tingkat hubungan many to many (M:M) antara tabel jadwal dan shift. tabel area_karyawan tercipta karena adanya tingkat hubungan many to many (M:M) antara tabel area dan tabel karyawan. Tingkat hubungan jadwal_area dan shift yaitu many to one (M;1). Tingkat hubungan jadwal dan jadwal yaitu many to one (M:1), tbl_user dan tbl_form sebagai fasilitas tambahan, dimana tabel user berfungsi untuk mneyimpan usernya dan password bagi yang memiliki akses sedangkan tbl_form merupakan fasilitas tambahan untuk menyimpan pengaturan terkait interface baik front end dan back end. 


\section{Use Case Diagram Usulan}

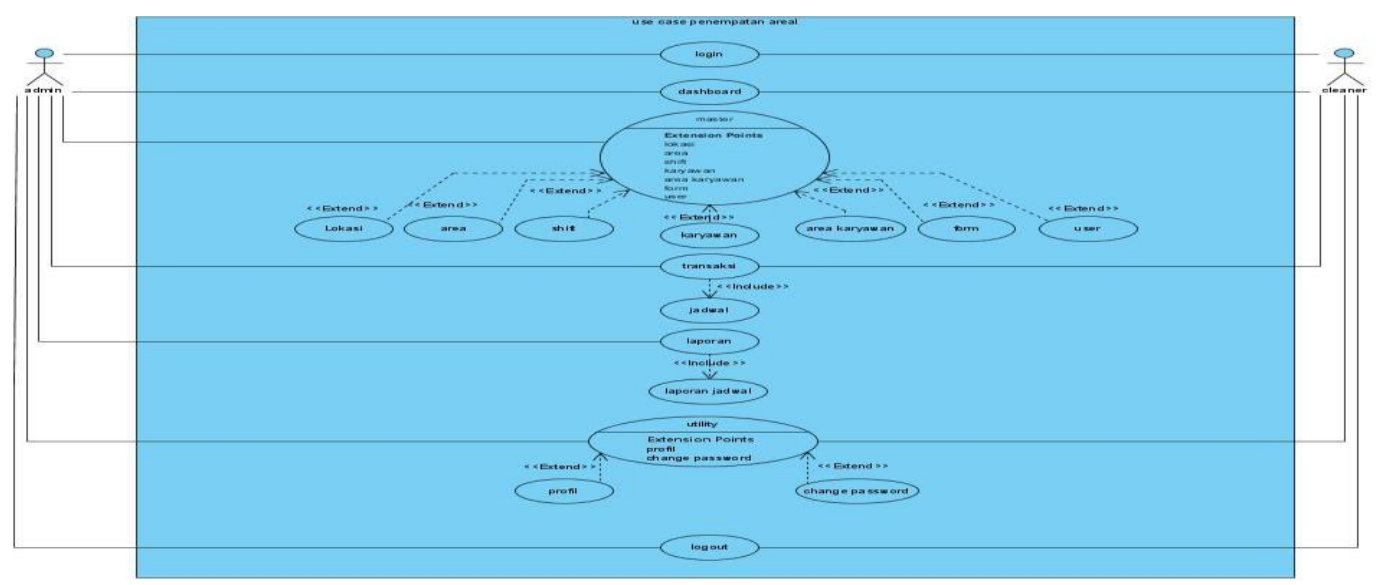

Gambar 5. Use Case Diagram

Berdasarkan gambar use case diagram usulan (gambar 5) terlihat jelas bahwa terdapat 18 (delapan belas) use case yang terdiri dari 4 (empat) use case utama yaitu master, transaksi, laporan, utility Use case master memiliki 5 (lima) yang terdiri dari user yang terhubung dengan actor user, lokasi , area kerja,shift, karyawan berhubungan dengan actor admin. Use case transaksi memiliki 1 (satu) yang terdiri dari laporan jadwal, yang terhubung dengan actor admin dan cleaner. Use case laporan memiliki 1 (satu) yang terdiri dari laporan jadwal yang terhubung dengan admin. Use case Utility memiliki 2 (dua) terdiri dari profil yang berfungsi untuk mengubah profil dan change password untuk mengganti password.

Use diagram sebagai bentuk rancangan sistem yang akan diciptakan (gambar 5) merupakan desain model tampilan utama yang berorintasi pada kebutuhan menu pada aplikasi yang disiapkan, selain itu untuk kebutuhan penyimanan informasi data agar dapat digunakan secara histori juga digambarkan dalam bentuk class diagram (gambar 4) lengkap dengan informasi field dan type data sesuai kebutuhan penyimpanan data.

\section{IMPLEMENTASI}

\section{Rancangan Basis Data}

Untuk dapat menggamarkan bentuk basis data secara utuh, peneliti penggunakan aplikasi microsoft access sebagai bentuk gambaran dasar, dan pada akhirnya bentuk rancangan basis data ini dapat disesuaikan menggunakan apa saja sesuai kebutuhan.

a. Tabel Master: User

Primary Key : No_user

Foreign Key : -

Structure Tabel $\quad: \quad\{$ No_user, User_login, Nama, Password, Akses, Profil \}

\begin{tabular}{|c|c|c|c|c|} 
No. & Nama Field & Tipe Data & Field Size & Keterangan \\
\hline $\mathbf{1}$ & No_user & Int & 3 & Primary Key \\
\hline $\mathbf{2}$ & User_login & Varchar & 50 & \\
\hline $\mathbf{3}$ & Nama & Varchar & 150 & \\
\hline $\mathbf{4}$ & Password & Varchar & 50 & \\
\hline $\mathbf{5}$ & Akses & Varchar & 50 & \\
\hline $\mathbf{6}$ & Profil & Varchar & 50 & \\
\hline
\end{tabular}

Tabel 1. Struktur User

b. Tabel Master: lokasi

Primary Key : id_lokasi

Foreign Key : : -

Structure Tabel $\quad: \quad\{$ id_lokasi, nama_lokasi, keterangan \} 


\begin{tabular}{|c|c|c|c|c|}
\hline No. & Nama Field & Tipe Data & Field Size & Keterangan \\
\hline $\mathbf{1}$ & id_lokasi & int & 11 & Primary Key \\
\hline $\mathbf{2}$ & nama_lokasi & varchar & 15 & \\
\hline $\mathbf{3}$ & keterangan & & & \\
\hline
\end{tabular}

Tabel 2. Struktur lokasi

c. Tabel Master: area

Primary Key : Kode_area

Foreign Key : -

Structure Tabel : \{kode_area, id_area, nama_area, keterangan \}

\begin{tabular}{|c|c|c|c|c|}
\hline No. & Nama Field & Tipe Data & Field Size & Keterangan \\
\hline $\mathbf{1}$ & Kode_area & Int & 11 & Primary Key \\
\hline $\mathbf{2}$ & Id_lokasi & Int & 11 & \\
\hline $\mathbf{3}$ & nama_area & Varchar & 25 & \\
\hline $\mathbf{4}$ & Keterangan & text & & \\
\hline
\end{tabular}

Tabel 3. Struktur area

d. Tabel Master: shift

Primary Key : kode_shift

Foreign Key : -

Structure Tabel : \{kode_shift, nama_shift, jam, ketrerangan \}

\begin{tabular}{|c|c|c|c|c|}
\hline No. & Nama Field & Tipe Data & Field Size & Keterangan \\
\hline $\mathbf{1}$ & kode_shift & varchar & 11 & Primary Key \\
\hline $\mathbf{2}$ & nama_shift & Varchar & 15 & \\
\hline $\mathbf{3}$ & jam & varchar & 20 & \\
\hline $\mathbf{4}$ & keterangan & text & & \\
\hline
\end{tabular}

Tabel 3. Struktur shift

e. Tabel Master: Jadwal

Primary Key : id_jadwal

Foreign Key

Structure Tabel $\quad: \quad\{$ id_jadwal, tanggal, keterangan $\}$

\begin{tabular}{c|c|c|c|c|}
\hline No. & Nama Field & Tipe Data & Field Size & Keterangan \\
\hline $\mathbf{1}$ & id_jadwal & varchar & 10 & Primary Key \\
\hline $\mathbf{2}$ & Tanggal & date & & \\
\hline $\mathbf{3}$ & keterangan & & & \\
\hline
\end{tabular}

Tabel 3. Struktur Jadwal

f. Tabel Master: karyawan

Primary Key : nip

Foreign Key : : -

Structure Tabel : \{nip, nama, jenis_kelamin, tgl_lahir, alamat, no_tlp, keterangan \}

\begin{tabular}{|c|c|c|c|c|}
\hline No. & Nama Field & Tipe Data & Field Size & Keterangan \\
\hline $\mathbf{1}$ & nip & varchar & 10 & Primary Key \\
\hline $\mathbf{2}$ & nama & Varchar & 50 & \\
\hline $\mathbf{3}$ & jenis_kelamin & Varchar & 12 & \\
\hline $\mathbf{4}$ & Tgl_lahir & Date & & \\
\hline $\mathbf{5}$ & alamat & Text & & \\
\hline $\mathbf{6}$ & no_tlp & Varchar & 13 & \\
\hline $\mathbf{7}$ & keterangan & Text & & \\
\hline
\end{tabular}

Tabel 3. Struktur karvawan 


\section{g. Tabel Master: Area Karyawan}

Primary Key : nip

Foreign Key : -

Structure Tabel $\quad: \quad\{$ nip, kede_area, keterangan $\}$

\begin{tabular}{|c|c|c|c|c|}
\hline No. & Nama Field & Tipe Data & Field Size & Keterangan \\
\hline $\mathbf{1}$ & Nip & Int & 11 & Primary Key \\
\hline $\mathbf{2}$ & Kode_area & Varchar & 10 & \\
\hline $\mathbf{3}$ & Keterangan & text & & \\
\hline
\end{tabular}

Tabel 3. Struktur Area karyawan

\section{h. Tabel Transaksi: Jadwal Area}

Primary Key : id_jadwal

Foreign Key : -

Structure Tabel $\quad: \quad\{$ id_jadwal, nip, kode_area, kode_shift, keterangan $\}$

\begin{tabular}{|c|c|c|c|c|}
\hline No. & Nama Field & Tipe Data & Field Size & Keterangan \\
\hline $\mathbf{1}$ & id_jadwal & varchar & 10 & Primary Key \\
\hline $\mathbf{2}$ & Nip & Varchar & 10 & \\
\hline $\mathbf{3}$ & Kode_area & int & 11 & \\
\hline $\mathbf{4}$ & int & Varchar & 11 & \\
\hline $\mathbf{5}$ & keterangan & text & & \\
\hline
\end{tabular}

Tabel 4. Struktur Jadwal Area

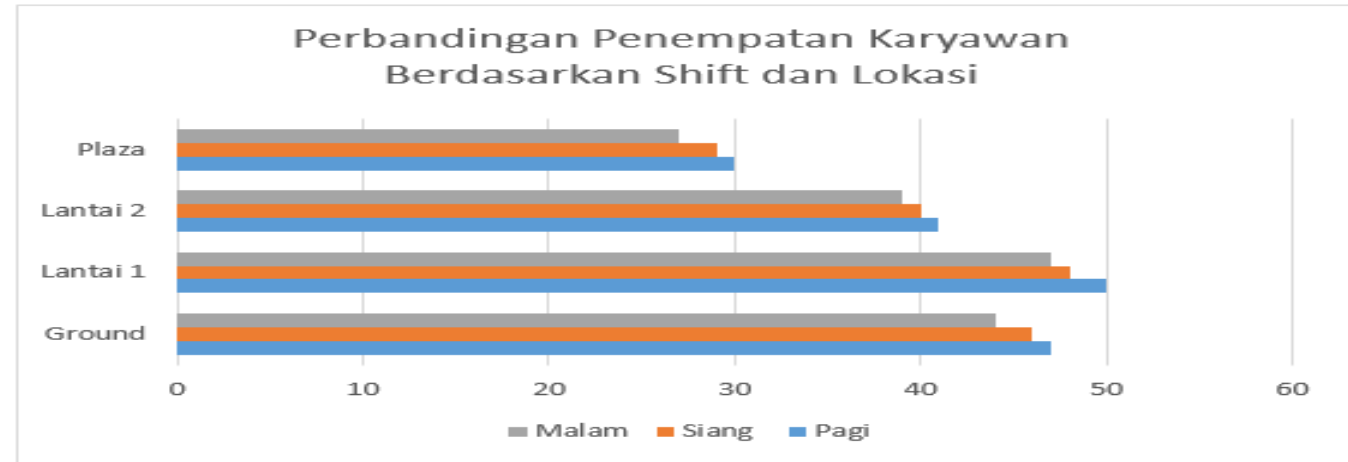

Gambar 6. Diagram Data Penepatan Karyawan

\section{Grafik Perbandingan Penempatan Karyawan Berdasarkan Shift dan Lokasi}

Grafik diatas (gambar 6) merupakan grafik perbandingan penempatan area kerja berdasarkan shift dan lokasi. Hal ini bisa membantu perusahaan untuk mengetahui kebutuhan cleaner berdasrkan shift dan lokasi. Grafik diatas bisa diambil berdasarkan Datewarehouse, sebagaimana di definisikan "Doing Data Warehouse $(D W)$ to your business or system is not only think about the trend only, but how to understand the DW knowledge itself and how to implement it" [14]. Dan bagaimana cara mengukurnya "Measures are a standard unit used to express the size, amount, or degree of something, qualities are often difficult to be measured as it needs to have some certain parameter or elements, and those parameters must be quantifiable and verifiable" [15]. 


\section{Diagram HIPO}

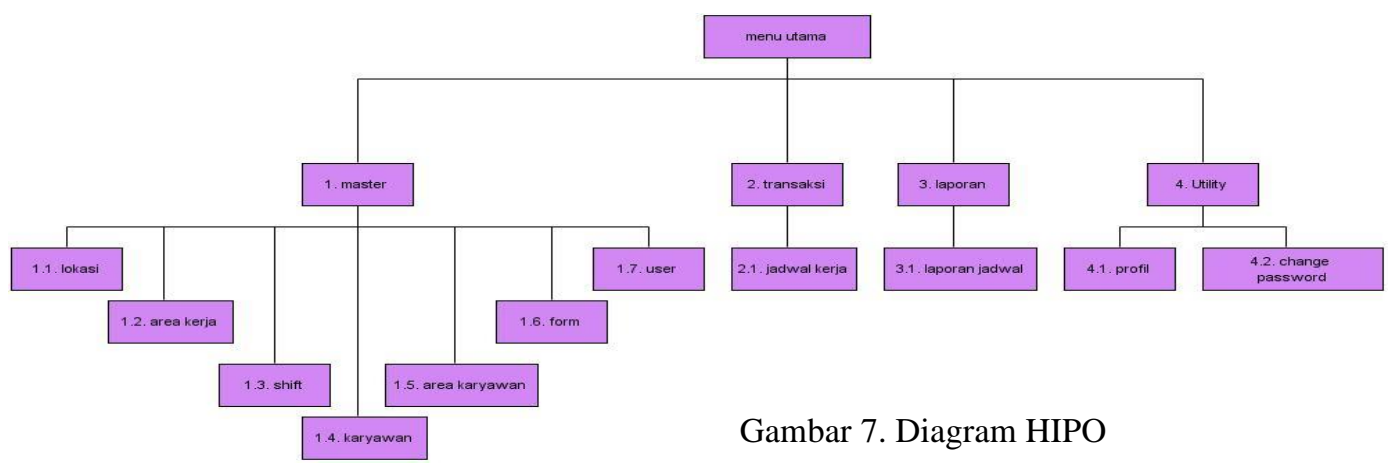

Untuk menggambarkan stuktur menu dari sistem yang dirancang dapat digambarkan dengan diagram HIPO (Hierarchy Input Process Output). Untuk menyediakan suatu struktur guna memahami fungsi-fungsi dari program. Terlihat dari diagram HIPO diatas (gambar 7) terdapat 1 (satu) fungsi utama (digram 0) dan 4 (empat) fungsi dibawahnya, yaitu fungsi menu master (diagram 1), menu transaksi (diagram 2), menu laporan (diagram 3) dan menu utility. Didalam fungsi menu master (diagram 1) terdapat 7 (tujuh) fungsi sub menu yaitu fungsi menu pengelolaan data lokasi (diagram 1.1), area kerja (diagram 1.2), shift (diagram 1.3), karyawan (diagram 1.4), area karyawan (diagram 1.5), form (diagram 1.6), dan user (diagram 1.7). Didalam fungsi menu transaksi (diagram 2) terdapat 1 (satu) fungsi menu jadwal laporan (diagram 2.1). Didalam fungsi laporan (diagram 3) terdapat 1 (satu) sub menu yaitu laporan jadwal (diagram 3.1). Didalam fungsi utility (diagram 4) terdapat 2 (dua) sub menu yaitu profil (diagram 4.1) dan change password (diagram 4.2).

\section{Rancangan Tampilan}

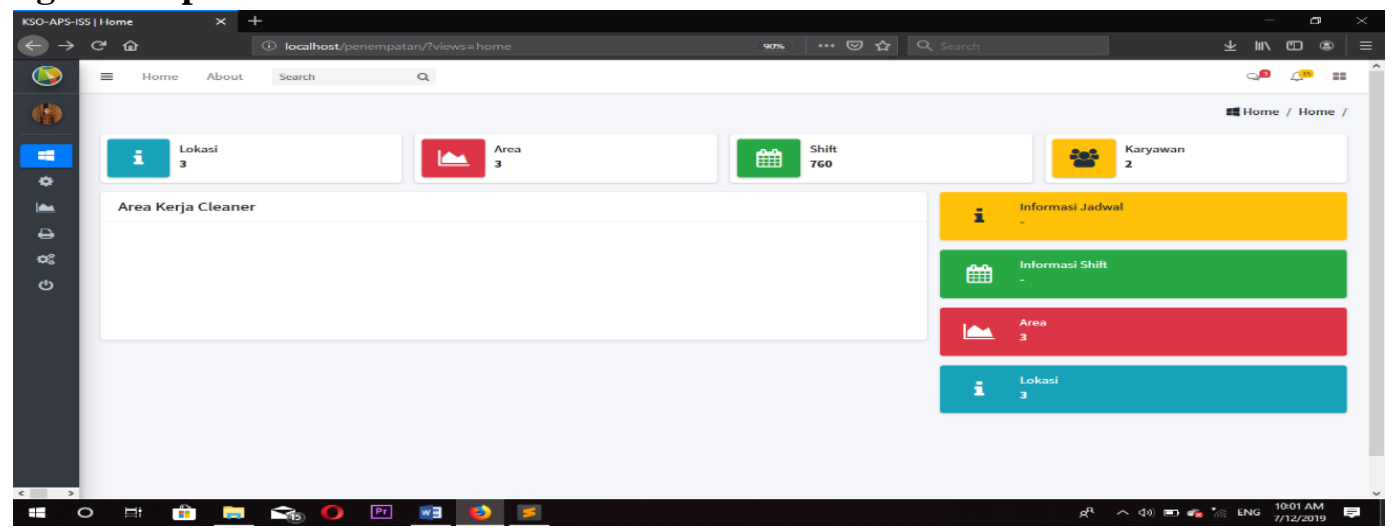

Gambar 8. Tampilan Utama

Terlihat pada tampilan layar diatas (gambar 8) merupakan tampilan layar utama yang terdiri dari menu master, menu transaksi, menu laporan dan utility.

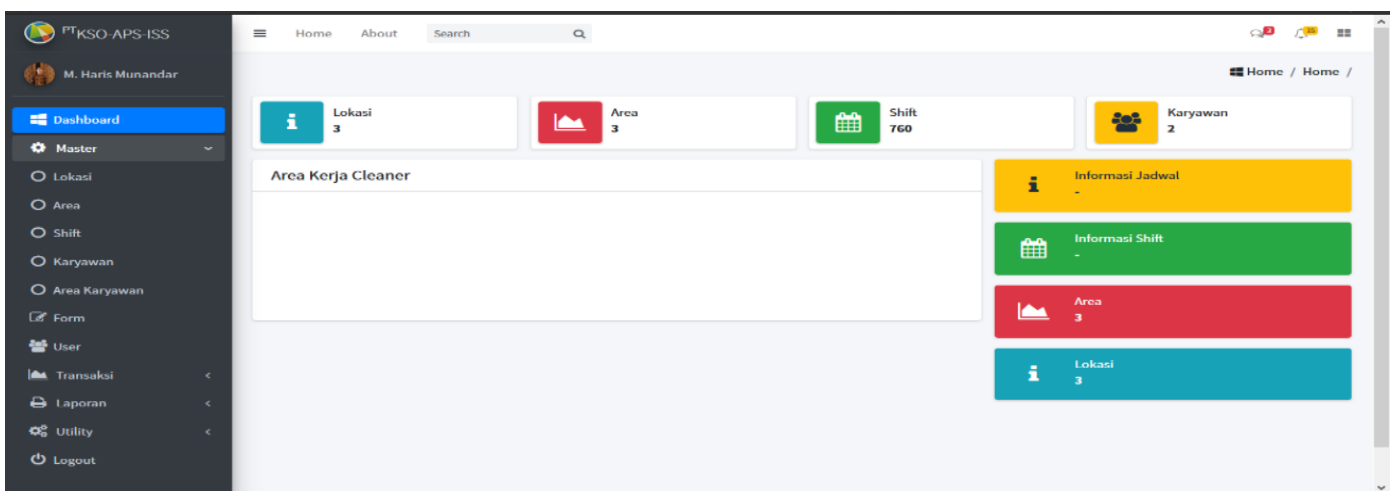

Gambar 9. Tampilan Menu master

Volume 5 No 2 Agustus 2019 
Terlihat pada tampilan layar diatas (gambar 9) merupakan tampilan layar utama yang terdiri dari menu master, menu transaksi, menu laporan dan menu utility dimana menu transaksi memiliki sub menu lokasi, area, shift, karyawan, area karyawan, form dan user.

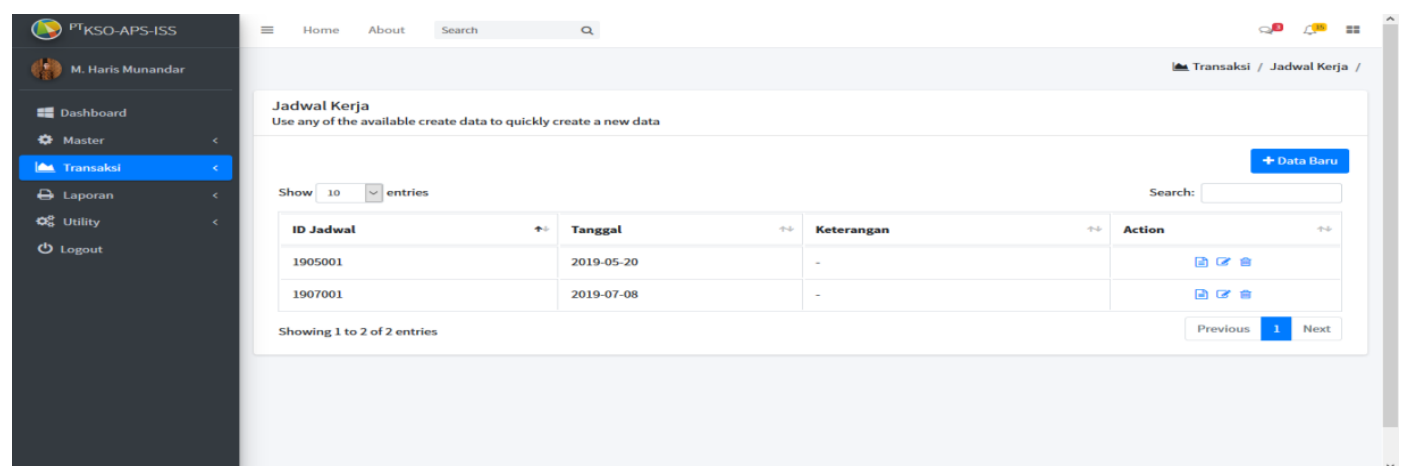

Gambar 10. Tampilan Menu Transaksi

Terlihat pada tampilan layar diatas (gambar 10) merupakan tampilan layar utama yang terdiri dari menu master, menu transaksi dan menu report, dimana menu report memiliki sub menu tagihan hutang supplier, jatuh tempo hutang, presentasi jatuh tempo dan estimasi pembayaran.

\section{Query Penciptaan Informasi}

Query Ubah Data Karyawan:

function edit_karyawan()

$\{\quad$ \$sql=" update tbl_karyawan

set

nip='".\$this->nip."',

nama="'.\$this->nama."',

jenis_kelamin='".\$this->jenis_kelamin."',

tanggal_lahir='".\$this->tanggal_lahir."',

alamat="'.\$this->alamat."',

no_telpon="'.\$this->no_telpon."',

keterangan $="$ ".\$this->keterangan."'

where nip="'.\$this->nip."'";

\$query=\$this->mysqli->query(\$sql) or die (\$this->mysqli->error());

return true;

\$this->mysqli->close(); \}

\section{Query Simpan Jadwal Area:}

function simpan_jadwal_area()

$\{\quad \$ s q l="$ insert into tbl_jadwal_area

set

id_jadwal="'.\$this->id_jadwal."',

kode_area="'.\$this->kode_area."',

nip='".\$this->nip."',

kode_shift='".\$this->kode_shift."',

keterangan='".\$this-> keterangan1."'";

\$query=\$this->mysqli->query( $\$$ sql) or die (\$this->mysqli->error());

return true;

\$this->mysqli->close(); \} 


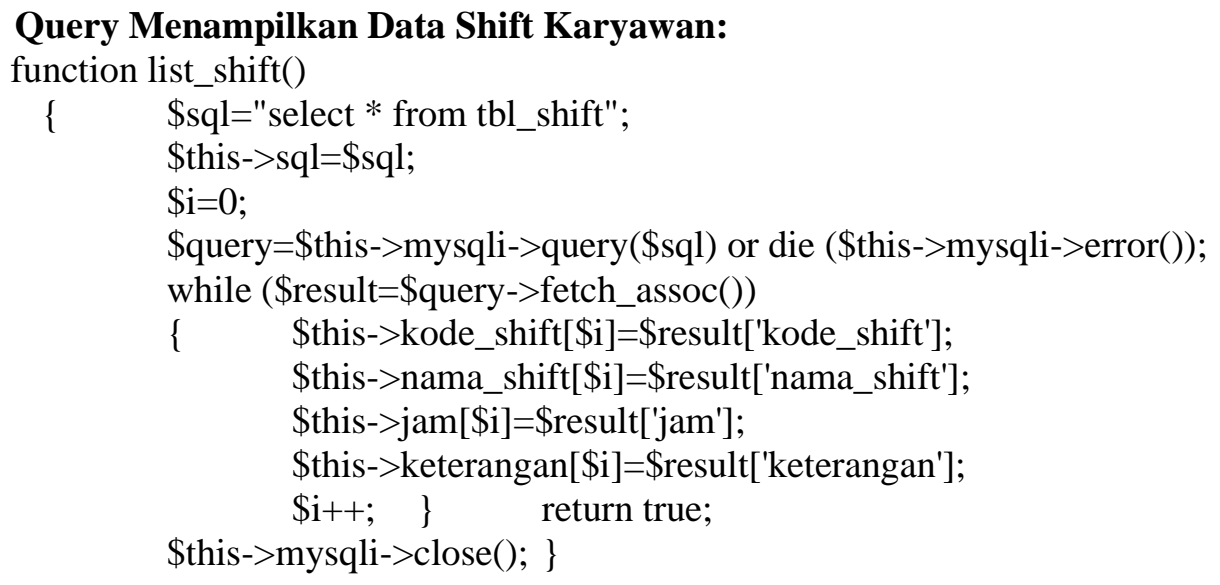

\section{KESIMPULAN}

Sistem penempatan area kerja yang saat ini masih belum terkomputerisasi yang memudahkan para pegawai dalam menentukan area kerja cleaner, sehingga belum berjalan dengan cepat pada prosesnya, selain itu juga belum memiliki tempat penyimpanan data sehingga masih sering terjadi kehilangan data yang menimbulkan masalah pada saat pencarian data, maka diperlukan media database agar data tersimpan dengan baik. Banyaknya pelaksana yang terlibat pada proses penempatan area kerja sekarang berlangsung, membuat kinerja para pegawai tidak maksimal pada saat di area. Seabagi solusi untuk semua ini, diperlukan adanya sistem yang direancangan dengan baik, sebagai media perancangan penulis menggunakan beberapa metode meliputi uml untuk perancangan, MySql untuk pengelolaan basis data, dan php sebagahai bahasa pemrograman, sehingga mampu menghasilkan sistem yang terkomputerisasi yang bias bekerja secara efektif dan efisien.

\section{DAFTAR PUSTAKA}

[1] Junaidi, J., Roji, A., \& Munawar, K. (2015). Konsep Otomatisasi Sistem Pembayaran SPP Online Untuk Mengurangi Tingkat Keterlambatan. Proceedings Konferensi Nasional Sistem dan Informatika (KNS\&I)..

[2] ARIF, Muhammad. Analisis Rekrutmen dan Penempatan Kerja terhadap Kinerja Karyawan pada Hotel Oase. Al-Hikmah: Jurnal Agama Dan Ilmu Pengetahuan, 2018, 15.1: 42-63. Diambil dari : http://journal.uir.ac.id/index.php/alhikmah/article/view/1584.

[3] Junaidi, T. K. Y. N. D. (2013). Sistem Pakar Monitoring Inventory Control Untuk Menghitung Harga Jual Efektif Dalam Meningkatkan Keuntungan. Yogyakarta: Universitas Ahmad Dahlan.

[4] Junaidi, Junaidi, Ridwan Arifin, and Amanda Septiani. "Rancang Bangun Aplikasi Sistem Inventory Berbasis Desktop Menggunakan JSE." Proceedings Konferensi Nasional Sistem dan Informatika (KNS\&I) (2015).

[5] Junaidi, J., Effendy, M. Y., \& Hartono, H. (2015). REKAYASA MODEL APLIKASI SISTEM PRODUCT KNOWLADGE UNTUK MENDUKUNG PENGAMBILAN KEPUTUSAN DALAM MENENTUKAN KINERJA KARYAWAN. CERITA Journal, 1(1), 46-55. 
[6] Henderi, H., Junaidi, J., \& Kusuma, T. A. H. (2012). Dashboard Monitoring System Penjualan Dan Reward Mobile Kios PT. Telekomunikasi Seluler. Semantik, 2(1)..

[7] Junaidi, J., Arifin, R., \& Septiani, A. (2015). Rancang Bangun Aplikasi Sistem Inventory Berbasis Desktop Menggunakan JSE. Proceedings Konferensi Nasional Sistem dan Informatika (KNS\&I)..

[8] Hidayat, Wahyu, Riri Mahmuriyah, dan Sri Ndayani Ratna Safitri. 2016. Media Visual Berbentuk Katalog Produk Sebagai Media Promosi. ISSN: 2461-1409. Jurnal SENSI Vol.2 No. 2-Agustus 2016. Tangerang : Perguruan Tinggi Raharja.

[9] Junaidi, J., Setianingsih, R., \& Khotimah, K. (2015). Rancang Bangun Sistem Penerimaan Dan Pengeluaran Barang Menggunakan Java Aplikasi. Proceedings Konferensi Nasional Sistem dan Informatika (KNS\&I)..

[10] Asbar, Yuli, dan Mochamad Ari Saptari. 2017. "Analisa Dalam Mengukur Kualitas Pelayanan Terhadap Kepuasan Konsumen Menggunakan Metode PIECES”. Jurnal Visioner \& Strategis Vol. 6 Nomor 2, September 2017: 39-47 Universitas Malikussaleh.

[11] Junaidi, J., Santoso, S., \& Sunarya, L. (2008). Rekayasa Teknik Pemrograman Pencegahan Dan Perlindungan Dari Virus Lokal Menggunakan API Visual Basic. CCIT Journal, 1(2), 134-153.

[12] Martono, A., \& Junaidi, D. Y. IMULATION GAME BASED ON JARIMAGIC METHOD TO CALCULATE MORE QUICKLY FOR ELEMENTARY STUDENTS.

[13] Junaidi, J., Cholisoh, N., \& Hasanah, N. (2018). Rancang Bangun Sistem Manajemen Aset IT Untuk Pencatatan History Maintenance Sebagai Pendukung Keputusan. SENSI Journal, 4(2), 220-231..

[14] M. Subekti, Warnars Junaidi, H.L.H.S., Y. Heryadi, "The 3 steps of best data warehouse model design with leaning implementation for sales transaction in franchise restaurant", Cybernetics and Computational Intelligence (CyberneticsCom) 2017 IEEE International Conference on, 20-22 Nov 2017.

[15] J. Junaidi, A. Julianto, N. Anwar, S. Safrizal, H.L.H.S. Warnars, K. Hashimoto, "Perfecting a Video Game with Game Metrics", Telkomnika, vol. 16, no. 3, pp. 13241331, June 2018 